\title{
Air quality improvement estimation using contingent valuation method in HoChiMinh City
}

- Nguyen Thi Ngoc

- Hoang Thi Kieu Oanh

- To Thi Hien

University of Sciences, VNU-HCM

(Manuscript received on $21^{\text {st }}$ October 2014, accepted on $22^{\text {nd }}$ December 2014)

\section{ABSTRACT}

The purpose of the study is to estimate the air quality improvement in the urban areas of HoChiMinh City (HCMC) through resident's willingness to pay (WTP) by using contingent valuation method. 300 residents were chosen to participate in an interview with the structured questionnaire and the open-ended question about their WTP. The results show that with the performance of ambient air in HCMC, $88.41 \%$ of respondents are willing to pay for this "particular commodity". The average WTP for a 50\% reduction of concentration of air pollutants in next 5 years in HCMC, where respondents live and work was 19,732
VNĐ/household/month, accounted $0.15 \%$ of a household income. Positive WTP values reveal that residents have a choice between better air quality and rapid growth of the economy, which also means that air quality is really their considerable economic value. Therefore, this value should be considered in the cost - benefit analysis of projects or programs relating to air quality. The results are the source of useful information for policy makers to decide in the investment and policy measures to reduce impacts on air quality in the process of economic development.

Keywords: air quality, contingent valuation method, willingness to pay, HoChiMinh City \section{INTRODUCTION}

HoChiMinh City (HCMC) is the biggest city in the south of Vietnam. Besides the rapid speed of economic development, transport, industry and construction activities caused a lot of impacts on ambient air. The monitoring system's results have showed negative signs on ambient air quality in recent years. Figure 1 describes some data in 2012 compared to the standard concentration. Evidence from studies around the world have shown that exposure to air pollutants may increase the rate of hospitalization and death because of respiratory and cardiovascular diseases [1-3]. However, the environmental management in HCMC has not attached importance to air quality partly because of budget limits as well as the lack in awareness on air quality protection. In Vietnam, costs of controlling air quality in provinces are taken from $1 \%$ of the budget for the annual environmental protection. Furthermore, these 
costs are $1 / 2$ and $1 / 10$ compared to costs of solid waste and wastewater management respectively [4]. Air quality has not been concerned and invested by managers. In fact, the automatic air monitoring system of HCMC stops working due to lack of funds for maintenance and calibration. In addition, the formulation of policies, emissions inventory, tools for air quality management, damage assessment, forecasting air pollution ... also need attention and require funds.
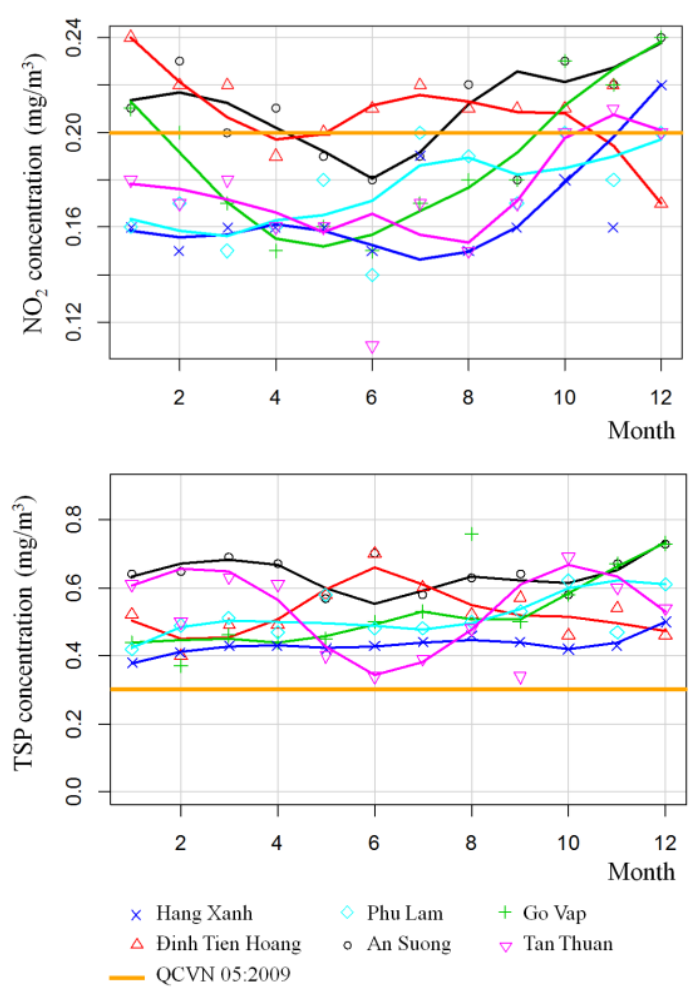

Figure 1. Monthly air pollutant concentrations in HCMC in 2012 [5]

\section{METHODS}

\section{Scenario and questionnaire design}

In scenario design, we tried to give respondents necessary information for making decision. There were information about major
How much is the value of improving air quality in the city? Is it worth to invest or not? Because air quality is one of non-market goods, we cannot use market prices to measure its economic value. Instead, we have to use another appropriate method which is measuring monetary value of changes in welfare to individuals associated with the change in environmental quality [6]. An empirical approach based on the view is the contingent valuation method (CVM) ignoring market prices and asking individuals directly to assess public goods or services $[7,8]$.

In Vietnam, the application of CVM is quite limited. There is no specific assessment of value of air quality. However, this problem has been considered in many countries with a lot of different study designs depending on local conditions and circumstances [9-11]...Some authors suggest that fresh air still being regarded as a kind of "luxury goods" [10-12].

Everyone wishes they can live in a healthy environment so an increase in air quality will certainly rise social welfare. We hypothesized that "residents in HCMC are willing to pay to improve air quality where they live and work". The study was designed to test this hypothesis using the CVM in order to assess the value of improving air quality through respondent's WTP.

sources of air pollution, the air quality status, impacts and an assumed air quality improvement project to reduce $50 \%$ concentration of contaminants making the air quality consistent

\section{Trang 6}


with the Vietnam air quality standard. In that, some solutions including controlling quantity and quality of transport, increasing public transport, improving the road system, planting more trees, parks, relocating industries and raising public awareness were listed. The works will require amount of money and people need to contribute to a fund. They will have to pay a fixed amount, collected monthly in the garbage bill of every household for 5 years. Some pictures and figures were used to illustrate for the information. In fact, the solutions were endorsed (from $48.19 \%$ to $70.65 \%)$ and the rate of respondents agreed with the payment method was $81.16 \%$.

The questionnaire was structured three components consisting of questions about subjective views of respondents related the current status of ambient air and improving air quality as well; questions about WTP to improve air quality in the city follow the scenario built; and questions about socio-economic information of respondents. For the WTP question, we choose the open-ended question type to simplify the questionnaire design because of lack of information from relevant researches in the area and to facilitate the data processing. This option will not affect results because the value of question types had been proved no significant difference [9]. To eliminate the uncertainty factor in the answer "yes" on the willingness to pay, respondents were reminded of their income limit and there were more options "yes, if ..." and "no answer" besides the answer "yes" and "no". The respondent answer "yes" or "yes, if..." will be asked the WTP question.

"How much is a maximum your family

\section{RESULTS AND DISCUSSION}

276 (92\%) questionnaires were recovered with effective information and used in the analyses. A very low ratio of participants not answering the WTP questions (2.67\%) indicated willing to contribute each month to achieve the goal of improving air quality in HCMC in the next 5 years? "

The questionnaire was also checked and adjusted through a pilot survey with 30 respondents having different socio-economic circumstances to ensure reasonable questionnaire and participants can understand information provided.

\section{Survey design}

The interviews were carried out simultaneously in the selected areas and directly by interviewers who were trained students of Environmental Science Faculty, University of Science in July 2013. The survey was conducted with 300 samples split evenly for road groups in District 3 and Tan Phu District representing for center and suburban areas respectively. In addition, participants over 18 years old (adults) were randomly selected on study areas and interview time was limited to about 15 minutes for once. To minimize bias that may occur during interviews, we provided for interviewers information about the study's purpose and unified conducts in situations.

\section{Data analysis}

We used R 3.0.2 program for statistical analyses [13]. The parametric statistic was used with the normal distribution of data. In fact, answers focusing on low WTP values made the data skewed to one side. Therefore, we used a logarithmic function to convert the data to a normal distribution forms and values used to analyze were $\operatorname{lnWTP}$.

that the questionnaire was constructed successfully. When compared characteristics of participants to the population in urban areas of HCMC, male ratio was $47.83 \%$ equivalent to the 
ratio in the population $(47.91 \%)$ [14]. Similarly, the adult group accounted for the highest percentage was 18-34 years old, education centralized in secondary and number of members in each family was 4 , but with small differences $45.65 \%, 35.51 \%$ and $32.61 \%$ compared to $50.84 \%, 33.86 \%$ and $25.14 \%$ respectively [15].

\section{Concern and awareness of residents}

Most participants expressed concerns about the ambient air quality in HCMC. $69 \%$ of respondents said the state of ambient air is from low to hazardous (people should stay indoors). $73.55 \%$ of respondents understood that air pollution was potentially harmful to ecosystem, environment and human health, but only $19.20 \%$ of respondents know of environmental standards. The main air pollution sources were transport, industry, waste, residential construction and livelihood activities in that order. Assessing the importance of improving air quality, $85 \%$ of

respondents commented that it was from important to very important and reasons based largely on direct impacts on themselves and their progeny (Figure 2).

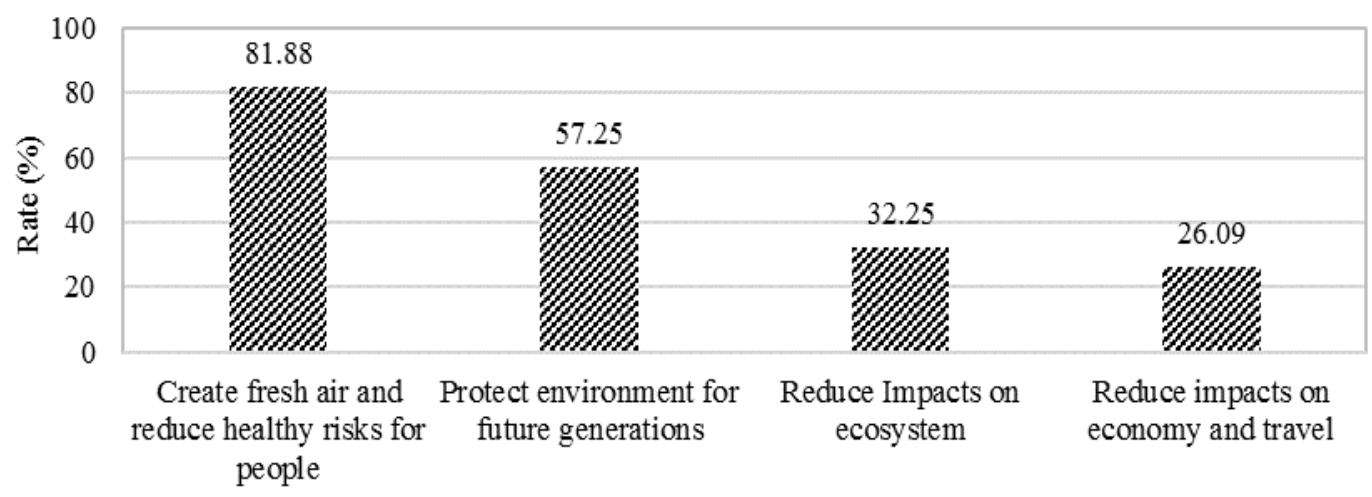

Figure 2. Reasons for improving air quality

\section{Willingness to pay for improving air quality}

The scenario was designed as a hypothetical market in the study, through which we created conditions so that respondents as consumers have the opportunity to purchase a particular commodity - the ambient air quality with specific information. Results are summarized in Table 1 , with $88.41 \%(244 / 276)$ of respondents willing to pay for this kind of commodities (WTP>0). Of these, $88 \quad(31.88 \%)$ responses expressed uncertainty by following conditions: "if the appropriate premium rate", "if they saw the positive development of the project"; "if the government had a policy" and "everyone had to pay"... Respondents (11.59\%) were not willing to pay for improving air quality and their reasons were listed in Table 2. The answer "the project is not necessary" and "do not believe in the project" could be considered as protests by a lack in awareness of the people on the importance of improving air quality. Respondents $(28.13 \%)$ said that "the responsibility belongs to the government" which could be explained by the free use of goods and environmental services in Vietnam made people give the less assessment than their true WTP.

\section{Trang 8}


After removing unclear answers and testing the normal distribution of data, the sample included in the next analyses was 150 . Exponential function was used to transform these values back to the prototype units of the original data (Table 3). The average WTP for a $50 \%$ reduction of concentration of air pollutants in urban areas in HCMC in the next 5 years was
19,732 VNĐ/ household/ month. Compared to $13,121,935 \mathrm{VN} Đ$ as an average monthly income of the household, WTP accounted for $0.15 \%$. The result of T-test also showed no significant difference in resident's WTP in the two districts which was consistent with the general level of socio-economic development in urban areas in HCMC.

Table 1. WTP for improving air quality in HCMC

\begin{tabular}{|l|l|l|}
\hline WTP (VNĐ) & Number of respondents & Rate $(\%)$ \\
\hline 0 & 32 & 11.59 \\
\hline$<10,000$ & 30 & 10.87 \\
\hline $10,000-20,000$ & 70 & 25.36 \\
\hline $20,000-40,000$ & 96 & 34.78 \\
\hline $40,000-60,000$ & 33 & 11.96 \\
\hline$\geq 60,000$ & 15 & 5.43 \\
\hline Total & 276 & 100 \\
\hline
\end{tabular}

Table 2. Respondent's reasons for negative WTP $(\mathrm{WTP}=0)$

\begin{tabular}{|l|l|l|}
\hline Reasons & $\begin{array}{l}\text { Number of } \\
\text { respondents }\end{array}$ & Rate (\%) \\
\hline 1. The project is not necessary & 1 & 3.13 \\
\hline 2. Do not have enough money to afford it & 9 & 28.13 \\
\hline 3. Do not believe in the project & 12 & 37.50 \\
\hline 4. Many different problems are important than air pollution & 0 & 0.00 \\
\hline 5. It is the government's responsibility & 9 & 28.13 \\
\hline 6. Do not want to pay through the garbage bill & 1 & 3.13 \\
\hline Total & 32 & 100 \\
\hline
\end{tabular}

Table 3. Statistic description of WTP, $n=150$

\begin{tabular}{|l|l|l|}
\hline & Mean & $95 \%$ Confident Interval \\
\hline $\ln$ WTP & 9.89 & $8.38-11.40$ \\
\hline WTP (VNĐ) & 19,732 & $4,359-89,322$ \\
\hline
\end{tabular}

The comparison with results of previous studies was difficult because there was a limited use of CVM in Vietnam. Pham Khanh Nam and Tran Vo Hung Son (2005) using CVM to determine the economic value of improving water services in the city reported a higher ratio of value of WTP/monthly income, about 3.5\% $4.6 \%$ [16]. This might be because the benefits of improving water supply services were recognized more easily than improving air quality. Also, the
WTP value found was much lower of different studies in the same field in neighboring countries, which confirmed the influence of the level of economic - social development. In China and Malaysia, the ratio was in the range of 0.5 $4.1 \%[9,10,17]$. Although the rate was quite small, resident's positive WTP proved that they had a choice between the better air quality and the fast speed of development of the economy. The WTP value was resident's assessment of 
benefits obtained by improving air quality in

\section{CONCLUSION}

Considering the relationship between poor air quality and WTP for improving air quality in HCMC, this study measured the monetary value of benefits of improving air quality. The results showed that the average WTP for a $50 \%$ reduction in concentration of pollutants in urban areas in HCMC was 19,732 VNĐ per household per month, occupied $0.15 \%$ of household income and no significant difference between two surveyed areas. Therefore, this value should be considered in the cost-benefits analysis of projects or programs relating to air quality.

Besides, the application of CVM in HCMC is entirely feasible. Logic and reliable results could be achieved through designing questionnaire and implementing survey accordingly. With increasing demand for higher urban areas of HCMC.

environmental quality, this will be a flexible and useful tool for policy makers in identifying priority environmental issues and investing effectively in pollution control, especially at time when the financial burden for environmental programs were transferred to provinces.

Acknowledgments. This study was supported by The Ryoichi Sasakawa Young Leader Fellowship Fund and VNUHCM - University of Sciences. We are grateful to Dr. Phan Thi Giac Tam from University of Agriculture and Forestry, HoChiMinh City, Vietnam for her valuable advice regarding survey design. We would also like to thank students of VNUHCM - University of Sciences who have supported us in interviewing community.

\section{Giá trị của việc cải thiện chất lượng không khí: một đánh giá ngẫu nhiên ở thành phố Hồ Chí Minh}

- Nguyễn Thị Ngọc

- Hoàng Thị Kiều Oanh

- Tô Thị Hiền

Trường Đại học Khoa học Tự nhiên, ĐHQG-HCM

\section{TÓM TẮT}

Mục tiêu của nghiên cứu nhằm đánh giá giá trị của việc cải thiện chất lượng không khí đô thị ở thành phố Hồ Chí Minh qua mức sãn lòng chi trả (Willingness to pay: WTP) của người dân bằng phương pháp đánh giá ngẫu nhiên. 300 người đã được chọn tham gia phỏng vấn với bảng câu hỏi cấu trúc và câu hỏi mở về mức sã̃n lòng chi trả của họ. Kết quả cho thấy: với hiện trạng chất lượng không khí xung quanh ở thành phố Hồ Chí Minh, 88,41\% người được hỏi sã̃n lòng chi trả cho loại "hàng hóa đặc biệt" này. Mức

Trang 10 
sãn lòng chi trả trung bình cho việc giảm $50 \%$ nồng độ các chất ô nhiễm trong 5 năm tới ở thành phố, nơi người trả lời sống và làm việc là 19.732 VNĐ/hộ/tháng, chiếm khoảng 0,15\% thu nhập của hộ. Giá trị tích cực của mức sã̃ lòng chi trả cho thấy rằng người dân có sự lựa chọn giữa chất lượng không khí tốt hơn và tốc độ phát triển nhanh của nền kinh tế. Chất lượng không khí thật sự là giá trị kinh tế đáng quan tâm của họ. Vì vậy, giá trị này nên được xem xét trong các phân tích chi phí - lợi ích của các dụ án, chương trình liên quan đến chất lượng không khí. Các kết quả là nguồn thông tin hữu ích cho các nhà làm chính sách trong các quyết định đầu tư công để giảm các tác động đến chất lượng không khí trong quá trình phát triển kinh tế.

Từ khóa: ô nhiễm khống khí, phương pháp đánh giá ngẫu nhiên, mức sã̃n lòng chi trả, thành phố Hồ Chí Minh

\section{REFERENCES}

[1]. Romieu I. S.J., Smith K.R., Bruce N., Outdoor air pollution and acute respiratory infections among children in developing countries, Journal of Occupational and Environmental Medicine 44, 640-649 (2002).

[2]. Braga A.L., Pereira L.A., Menezes J.J., Conceicao G.M., Lin C.A., Zanobetti A., Schwartz J., Dockery D.W., Health effects of air pollution exposure on children and adolescents in Sao Paulo, Brazil, Pediatr Pulmonol 31, 106-113 (2001).

[3]. World Health Organization, Guidelines for air quality, the World Health Organization, Geneva (2000).

[4]. Ministry of Natural Resources and Environment, The national evironmental report 2013 - The ambient air, Hanoi, Vietnam (2014) (in Vietnamese).

[5]. HoChiMinh City Environmental Protection Agency (HEPA), Air Quality Briefing of HoChiMinh City, HoChiMinh City, Vietnam (2013) (in Vietnamese).

[6]. John C.B., Concepts and Measures of the Economic Value of Environmental Quality: a Review, Journal of Environmental Management 31, 215-228 (1990).

[7]. Kerry Turner R., David P., Ian B.,
Environmental economic, East Anglia University and London University (1995).

[8]. Richard D., The theory of the contingent valuation method, Hume Paper on Public Policy 6, 67-89 (1998).

[9]. Afroz R., Hassan M.N., Awang M., Ibrahim N.A., Willingness to pay for air quality improvements in Klang Valley Malaysia, American Journal of Environmental Sciences 1, 194-201 (2005).

[10].Wang X.J., Zhang W., Li Y., Yang K.Z., Bai M., Air quality improvement estimation and assessment using contingent valuation method, a case study in Beijing, Journal of Environmental Monitoring and Assessment 120, 153-168 (2006).

[11].Carlsson F., Johansson-Stenman O., Willingness to pay for improved air quality in Sweden, Applied Economics 32, 661-669 (2000).

[12]. Wang H., Mullahy J., Willingness to pay for reducing fatal risk by improving air quality: A contingent valuation study in Chongqing, China, Science of the Total Environment 367, $50-57$ (2006).

[13].R Core Team, $R: A$ language and environment for statistical computing, $\mathrm{R}$ Foundation for Statistical Computing, 
Vienna, Austria (2013).

[14]. Statistical Office of HoChiMinh City, Statistical Yearbook, Thong Ke, HoChiMinh City, Vietnam (2011) (in Vietnamese).

[15].The General Statistics Office, Census of population and house in Vietnam, Thong Ke, Vietnam (2009) (in Vietnamese).
[16].Nam P.K, Son T.V.H, Household Demand for Improved Water Services in Ho Chi Minh City: A Comparison of Contingent Valuation and Choice Modeling Estimates. Economy and Environment Program for Southeast Asia (2005).

[17]. Wang Y., Zhang Y.S., Air quality assessment by contingent valuation in Ji'nan, China, Journal of Environmental Management 90, 1022-1029 (2009). 